\title{
Histopathological changes in liver and gill epithelium of Nile tilapia, Oreochromis niloticus, exposed to waterborne copper ${ }^{1}$
}

\author{
António Figueiredo-Fernandes ${ }^{2}$, Jorge V. Ferreira-Cardoso ${ }^{2}$, Sofia Garcia-Santos ${ }^{2}$, \\ Sandra M. Monteiro ${ }^{2}$, João Carrola ${ }^{2}$, Pedro Matos $^{2}$ and António Fontaínhas- \\ Fernandes $^{2 *}$
}

\begin{abstract}
Figueiredo-Fernandes A., Ferreira-Cardoso J.V., Garcia-Santos S., Monteiro S.M., Carrola J., Matos P. \& Fontaínhas-Fernandes A. 2007. Histopathological changes in liver and gill epithelium of Nile tilapia, Oreochromis niloticus, exposed to waterborne copper. Pesquisa Veterinária Brasileira 27(3):103-109. University of Trás-os-Montes and Alto Douro, Center of Studies on Technological of Environmental and Life Sciences (CETAV), Apartado 1013, Vila Real 5001-801, Portugal. E-mail: fontain@utad.pt

Nile tilapia, Oreochromis niloticus, of both sexes were reared in freshwater and exposed to $0.5,1.0$ and $2.5 \mathrm{mg} \mathrm{L}^{-1}$ of waterborne copper for a period of 21 days. Liver and gill samples were collected after 21 days of exposure to copper and lesions were analyzed by light microscopy. The main histopathological changes observed in gills exposed to the highest concentration were edema, lifting of lamellar epithelia and an intense vasodilatation of the lamellar vascular axis. Although less frequent, lamellar fusion caused by the filamentar epithelium proliferation and some lamellar aneurisms were also found. The liver of control group exhibited a quite normal architecture, while the fish exposed to copper showed vacuolation and necrosis. These hepatic alterations were more evident in fish exposed to 1.0 and $2.5 \mathrm{mg} \mathrm{L}^{-1}$ copper concentrations. The number of hepatocytes nucleus per $\mathrm{mm}^{2}$ of hepatic tissue decreased with the increase of copper concentration. In contrast, the hepatic somatic index was high in fish exposed at $2.5 \mathrm{mg} \mathrm{L}^{-1}$ of copper. In short, this work advance new knowledge as influence of copper in the gill and liver histology of $O$. niloticus and demonstrated that their effects could be observed at different concentrations.
\end{abstract}

INDEX TERMS: Copper, gill, liver, histopathological changes, Oreochromis niloticus, Teleostei.

RESUMO.- [Alterações histopatológicas no epitélio hepático e branquial da Tilápia do Nilo, Oreochromis niloticus, exposta a diferentes concentrações de cobre.] Tilápia do Nilo, Oreochromis niloticus, de ambos os sexos foram mantidas em água doce e expostas a concentrações de $0.5,1.0$ e $2.5 \mathrm{mg} \mathrm{L}^{-1}$ de sulfato de cobre durante um período de 21 dias. Amostras de fígado e de brânquia foram coletadas após o tempo de exposição e as lesões foram analisadas por microscopia óptica. As principais alterações histopatológicas observadas nas brânquias foram edema, "lifting" do epitélio lamelar e uma

\footnotetext{
${ }^{1}$ Received on September 11, 2006.

Accepted for publication on December 28, 2006.

2 Depto Engenharia Biológica e Ambiental, Universidade de Trás-os-Montes e Alto Douro, Apartado 1013, Vila Real 5001-801, Portugal. "Corresponding author: fontain@utad.pt
}

intensa vasodilatação do eixo lamelar. Embora menos freqüentes, a fusão lamelar causada pela proliferação do epitélio filamentar e alguns aneurismas lamelares também foram observadas. $O$ fígado do grupo controle exibiu uma arquitetura normal, enquanto os dos peixes expostos ao cobre apresentaram vacuolização e necrose. Estas lesões hepáticas foram mais evidentes nos peixes expostos a concentrações de cobre de 1.0 e $2.5 \mathrm{mg} \mathrm{L}^{-1}$. O número dos núcleos dos hepatócitos / $\mathrm{mm}^{2}$ de tecido hepático decresceu com o aumento da concentração de cobre. Em contraste, o índice hepatossomático foi mais elevado nos peixes expostos a $2.5 \mathrm{mg} \mathrm{L}^{-1}$ de cobre. Em resumo, este trabalho acrescenta nova informação sobre a influência do cobre ao nível da histologia da brânquia e do fígado de 0 . niloticus e demonstra que os seus efeitos podem ser observados em diferentes concentrações.

TERMOS DE INDEXAÇÃO: Cobre, brânquia, fígado, alterações histológicas, Oreochromis niloticus. 


\section{INTRODUCTION}

Copper is an essential trace metal in small concentrations for several fish metabolic functions. Essentiality of copper arises from its specific incorporation into a variety of enzymes which play important roles in physiological processes (e.g. enzymes involved in cellular respiration, free radical defence, neurotransmitter function, connective tissue biosyntheses and other functions), as well as, into some structural proteins (WHO 1998).

Although the crucial role of copper in several enzymatic processes (Baker 1969, Li et al. 1998), this heavy metal can exert adverse toxicological effects, when present in high concentrations in water (Pelgrom et al. 1995). In fact, it is potentially toxic when the internal available concentration exceeds the capacity of physiological detoxification processes.

Increasing agricultural production has resulted in increasing number of freshwater systems being impacted by the contaminants present in wastewater releases. In Portugal copper has been used in viticulture to control fungal diseases in vineyard plants. High concentrations of this heavy metal were detected in some aquatic ecosystems collecting vineyard runoff water and it is also highly concentrated in ground water (Gerbe 1996, Teisseire 1999). There are also anthropogenic sources of environmental contamination by copper including mining, smelting, foundries, municipal waste incinerators, burning of coal for power generation and a variety of copper-based products used in building and construction (Nor 1987, WHO 1998).

Heavy metal contamination has been reported in aquatic organisms (Adham et al. 2002, Olojo et al. 2005). These pollutants build up in the food chain and are responsible for adverse effects and death in the aquatic organisms (Farkas et al. 2002). Fish are widely used to evaluate the health of aquatic ecosystems and physiological changes serve as biomarkers of environmental pollution (Kock et al. 1996). Nile tilapia, Oreochromis niloticus, is one of the most common freshwater fish used in toxicological studies (Figueiredo-Fernandes et al. 2006a,b, Garcia-Santos et al. 2006), because it present a number of characteristics that may make it an appropriate model that can be used as indicator species in biomonitoring programmes (Gadagbui et al. 1996).

When exposed to toxic concentrations, organs of aquatic animals may accumulate copper (Pelgrom et al. 1995, Grosell et al. 1996, Mazon et al. 2002), which can lead to redox reactions generating free radicals and, therefore, may cause biochemical and morphological alterations (Varanka et al. 2001, Monteiro et al. 2005). Gills are the first target of waterborne pollutants due to the constant contact with the external environment, as well as the main place for copper uptake (Campbell et al. 1979, Perry \& Laurent 1993). It is well known that changes in fish gill are among the most commonly recognized responses to environmental pollutants (Mallatt 1985, Laurent \& Perry 1991, Au 2004).

The liver was examined because it plays a primary role in the metabolism and excretion of xenobiotic compounds with morphological alterations occurring in some toxic conditions
(Rocha \& Monteiro 1999). Metals can either increase or decrease hepatic enzyme activities and can lead to histopathological hepatic changes, depending on the metal type and concentration, fish species, length of exposure and other factors (Paris-Palacios et al. 2000). The monitorization of histological changes in fish liver is a highly sensitive and accurate way to assess the effects of xenobiotic compounds in field and experimental studies.

Hence, this study was undertaken to examine the effect of different sublethal copper sulphate concentrations on histological aspects of gill and liver of Nile tilapia, Oreochromis niloticus.

\section{MATERIALS AND METHODS}

\section{Fish and experimental system}

Nile tilapia, Oreochromis niloticus, Teleostei (Bouaké strain) were originally obtained from the Institute Nationale de Recherche Agronomique (Rennes, France) and raised in the Aquaculture Station of the University of Trás-os-Montes and Alto Douro (UTAD, Vila Real, Portugal) for three generations. The fish used for this experiment were maintained in $100 \mathrm{~L}$ recirculating tanks, filled with dechlorinated tap water ( $\mathrm{pH}$ 6.5-7.5; alkalinity $60 \mathrm{mg} \mathrm{L}^{-1}$ as $\mathrm{HCO}^{3-}$; conductivity $63 \mu \mathrm{Scm}^{-1} ; \mathrm{Na}^{+}, 14 \mathrm{mg} \mathrm{L}^{-1} ; \mathrm{K}^{+}, 2.3 \mathrm{mg} \mathrm{L}^{-1} ; \mathrm{Ca}^{2+}, 4.1 \mathrm{mg} \mathrm{L}^{-1} ; \mathrm{Mg}^{2+}$, $6.5 \mathrm{mg} \mathrm{L}^{-1} ; \mathrm{Cl}^{-}, 19.5 \mathrm{mg} \mathrm{L}^{-1} ; \mathrm{NO}^{3-}, 27 \mathrm{mg} \mathrm{L}^{-1} ; \mathrm{NO}^{2-}, 0.5 \mathrm{mg} \mathrm{L}^{-1}$ ). Fish were fed daily to satiation with a previous tested diet (FontaínhasFernandes et al. 1999), kept at a constant temperature of $25 \pm 1^{\circ} \mathrm{C}$ and controlled photoperiod (12D: 12L). Supplemental aeration was provided to maintain dissolved oxygen near saturation.

Sexually mature tilapia 0 . niloticus $(35.3 \pm 5.4 \mathrm{~g}$ of mean body weight) were randomly distributed through 12 tanks of $100 \mathrm{~L}$. There were 3 fish per tank and 3 tanks for each treatment in a total of $\mathrm{n}=$ 36. Fish from 3 tanks containing water without copper served as the control group. Fish from the remaining tanks were exposed to water copper concentrations of $0.5,1.0$ and $2.5 \mathrm{mg} \mathrm{L}^{-1}$, supplied as copper sulphate $\left(\mathrm{CuSO}_{4}\right.$; MERCK, Lisbon, Portugal), during 21 days. The copper concentrations were selected based on preliminary results, shown to be sublethal after a 21 day period of exposure. The experiments were carried out under constant temperature $(25 \pm$ $1^{\circ} \mathrm{C}$ ), controlled photoperiod (12D: $12 \mathrm{~L}$ ) and constant filtration. The water had identical physical and chemical characteristics of the acclimation tanks and the experiments described comply with the Guidelines of the European Union Council (86/609/EU). Both control and experimental tanks were submitted to a rate of water renovation of $1 / 3$ every two days. The water quality parameters mentioned above were assessed in the experimental period, with no significant changes being observed. During the experimental period fish were once daily fed the referred diet to visual satiation and were fasted for $24 \mathrm{~h}$ before sampling.

No fish mortality was observed during the experiment. Six fish per treatment ( 2 fish per tank) were anaesthetized with 2 phenoxiethanol (Sigma, Barcelona, Spain) $\left(1 \mathrm{ml} \mathrm{L}^{-1}\right.$ water), weighed and sampled. Gills and livers were collected and weighed at 21 days of exposition.

\section{Histology}

A gill arch of the right side of each fish was collected and fixed in Bouin's fluid for $24 \mathrm{~h}$, dehydrated in graded ethanol concentrations and embedded in paraffin wax. Sagittal sections $(5 \mu \mathrm{m}$ of thickness) were cut and mounted on glass slides. Sections were deparaffinized in xylene, hydratated in ethanol and stained with hematoxylin-eosin (HE). The liver was quickly dissected, sliced into 
3mm thick slabs, and immersed in Bouin's fixative for $24 \mathrm{~h}$, dehydrated, and embedded in paraffin; a minimum of 5 pieces resulted. Histological sections ( $5 \mu \mathrm{m}$ of thickness) were cut and stained with H\&E. Changes induced by treatment in the gill and liver tissues were photographed and analyzed by light microscopy (Nikon ${ }^{\circledR}$ Labophot).

The hepatossomatic index (HSI) was calculated and the number of hepatocytes nucleus per $\mathrm{mm}^{2}$ of hepatic tissue was obtained in 12 microscopic fields (100x). Means \pm standard deviation (SD) were calculated for each experimental group. Statistical differences between exposed groups and respective control group were analysed using ANOVA and multiple comparison by StudentNewman-Keuls test, at a 5\% significant level. All tests were performed using the software STATISTICA, version 6.0 (StatSoft Inc. 2001).

\section{RESULTS}

The gill morphology of the control tilapia is similar to that of other teleost fish species (Wilson \& Laurent 2002). The gill is made up of double rows of filaments from which arise perpendicularly the lamellae. The lamellae are lined by a squamous epithelium composed by pavement and nondifferentiated cells. Below that epithelium are lamellar blood sinuses separated by pillar cells. Between the lamellae, the filament is lined by a thick stratified epithelium constituted by several cellular types, such as chloride, mucous and pavement cells (Fig.1A). Fish showed some signs of epithelial lesions when exposed to the highest concentration, $2.5 \mathrm{mg} \mathrm{L}$ ${ }^{1} \mathrm{CuSO}_{4}$ (Fig.1B, C, D, E). The main changes observed after 21
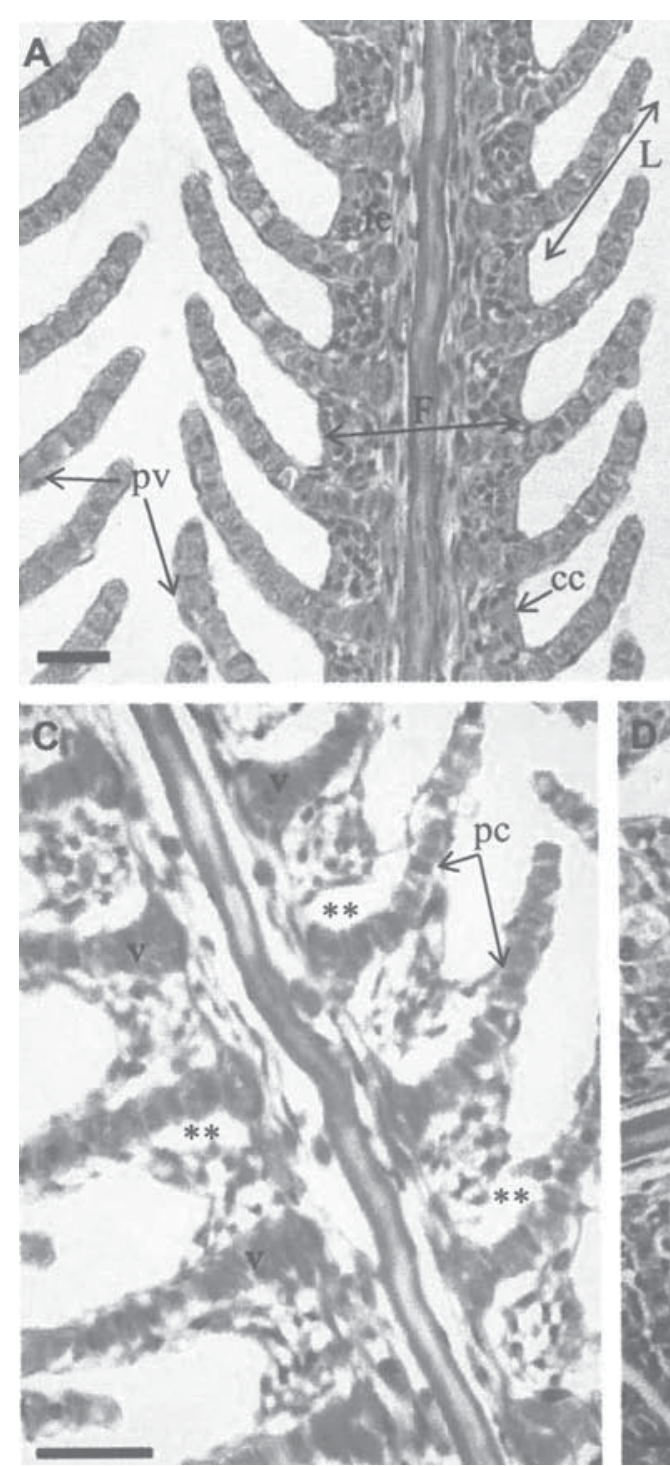

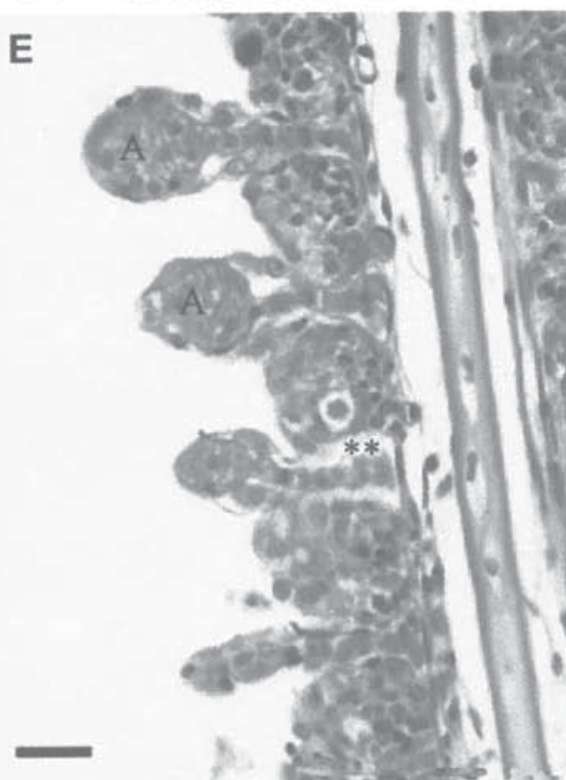

Fig.1. Representative light micrographs of gills in control and copper treated (B-E, $2.5 \mathrm{mg}-\mathrm{l} \mathrm{CuSO4,} 21$ days) tilapia, Oreochromis niloticus. (A) Control fish, showing normal appearance of gill filaments (F) and lamellae (L). (B) Gills from exposed fish showing an intense lamellar epithelium lifting (Lf). Note the epithelium proliferation in the above filament (FP). (C) Section of gill with lamellar axis vasodilation (v) and evident epithelium interstitial edema (**) in the filament near the lamellar axis. (D) Proliferation of filamentar epithelium (Fp) with fusion of adjacent lamellae (Lfu). (E) Gill epithelium of treated fish showing vascular congestion or lamellar aneurisms (A). cc $=$ chloride cell, cvs $=$ central venous sinus, fe $=$ filament epithelium, $\mathrm{pc}=$ pillar cell, $\mathrm{pv}=$ pavement cell. $\mathrm{HE}$, bars $=20 \mu \mathrm{m}$. 
days of exposure were accentuated lifting of the lamellar epithelium (Fig.1B), edema in the filamentar epithelium and an intense lamellar vasodilation (Fig.1C). The gills of some fish also exhibited lamellar fusion in numerous areas (Fig.1D)

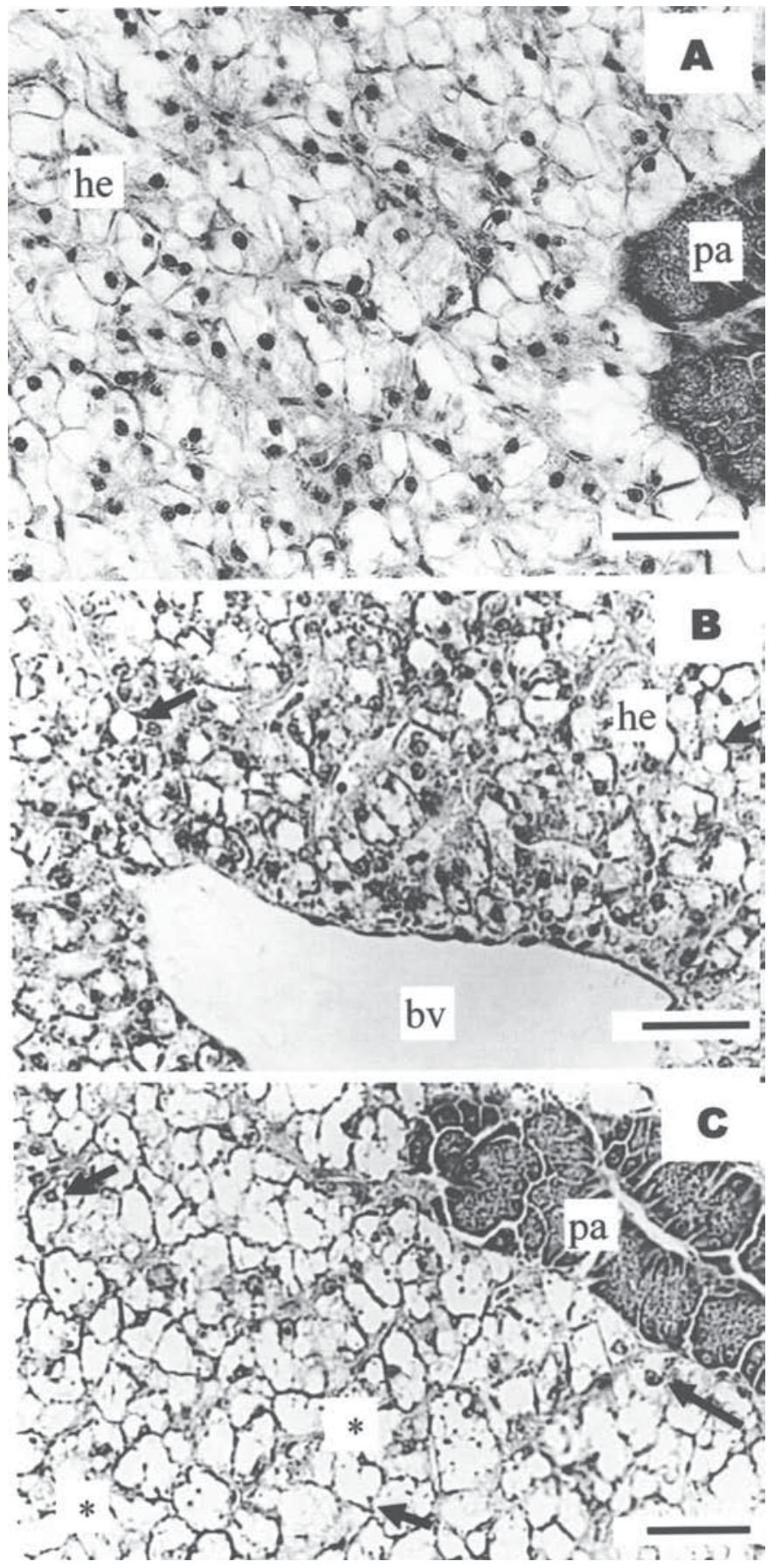

Fig.2. Photomicrographs of Nile tilapia Oreochromis niloticus liver tissue. (A) Control group showing hepatocytes (he) and pancreatic area (pa) that corresponds to the acini of exocrine pancreas. (B) Liver of fish exposed to copper (1 mgL-1), showing alterations in hepatocytes and vacuolation (black arrows); bv, blood vessel. (C) Liver of fish exposed to copper (2.5 mgL-1), showing vacuolation (black arrows) and necroses area (*) and picnotic nucleus (black arrow).HE, bars $=50 \mu \mathrm{m}$
Table 1. Hepatossomatic index (HSI) and number of hepatocyte nucleus per mm of hepatic tissue (Hepat.nucl. $\mathrm{mm}^{-2}$ ) measured in Nile tilapia Oreochromis niloticus exposed to different copper sulphate concentrations for 21 days $^{a}$

\begin{tabular}{ccc}
\hline$\left[\mathrm{CuSO}_{4}\right]\left(\mathrm{mg} . \mathrm{L}^{-1}\right)$ & HSI & Hepat.nucl.mm \\
\hline 0 & $0.98 \pm 0.0008^{\mathrm{a}}$ & $15484.76 \pm 1023.97^{\mathrm{a}}$ \\
0.5 & $1.44 \pm 0.0011^{\mathrm{b}}$ & $5476.29 \pm 1376.93^{\mathrm{b}}$ \\
1.0 & $1.52 \pm 0.0023^{\mathrm{b}}$ & $3096.82 \pm 747.07^{\mathrm{c}}$ \\
2.5 & $2.02 \pm 0.0023^{\mathrm{c}}$ & $1482.27 \pm 669.93^{\mathrm{d}}$
\end{tabular}

a Values are expressed as means $\pm S E(n=6)$. Means in the same column with different letters are significantly different (ANOVA, $\mathrm{P}<0.05$ ).

as a result of filamentar epithelium proliferation (Fig.1B, D). In addition, a few aneurisms were also observed at gill lamellae (Fig.1E).

Liver histology from control and exposed fish is briefly illustrated in Fig.2. In the control group, the liver exhibited a normal architecture and there were no pathological abnormalities, with hepatocytes presenting a homogenous cytoplasm, and a large central or subcentral spherical nucleus (Fig.2A). The hepatic parenchyma of fish exposed to copper showed lower eosinophilia and an increase of cytoplasmatic vacuolation (Fig.2B, C). Additionally, tilapias exposed to copper also showed hepatocellular necrosis (Fig.2C). These liver histological alterations were more evident in fish exposed to 1.0 and $2.5 \mathrm{mg} \mathrm{L}^{-1}$ copper concentrations. The HSI increased with the copper concentration (Table 1). However, the number of hepatocytes nucleus per $\mathrm{mm}^{2}$ of hepatic tissue decreased with the increase of copper concentration (Table 1).

\section{DISCUSSION}

Histological study of the gills shows a typical structural organization of the lamella in the untreated fish. However, fish exposed to copper shows several histological alterations, namely lamellar epithelium lifting, epithelium proliferation, lamellar axis vasodilation, edema in the filament, fusion of lamellae and lamellar aneurisms.

Some studies revealed that interstitial edema is one of the more frequent lesions observed in gill epithelium of fish exposed to heavy metals (Mallatt 1985). The results of this study confirm the occurrence of edema independently of copper levels, as in other fish species (Sola et al. 1995, Bury et al. 1998). The lifting of lamellar epithelium is other histological change observed, probably induced by the incidence of severe edema (Arellano et al. 1999, Pane et al. 2004, Schwaiger et al. 2004).

Edema with lifting of lamellar epithelium could be serve as a mechanism of defense, because separation epithelial of the lamellae increases the distance across which waterborne pollutants must diffuse to reach the bloodstream (Arellano et al. 1999). These gill histological alterations has been observed by several authors in fish submitted to copper (Karan et al. 1998, Chen \& Lin 2001, De Boeck et al. 2001). However, these changes also can be due to the exposition to different kinds of pollutants, such as endosulfan (Nowak 1992), arsenic (Hwang \& Tsai 1993), drugs (Schwaiger et al. 2004) and other 
heavy metals, as aluminium (Karlsson-Norggren et al. 1986), cadmium (Reid \& McDonald 1988), and nickel (Pane et al. 2004). Thus, this signifies that these alterations are not specifically induced by copper or other heavy metals.

Cell proliferation with thickening of gill filament epithelium is one histological change found in fish exposed to copper by several authors (Arellano 1999, De Boeck et al. 2001, van Heerden et al. 2004), and may lead to the lamellar fusion observed in this study. These results also were found in fish exposed to other pollutants (Randi et al. 1996, Van den Heuvel et al. 2000, Rosety-Rodríguez et al. 2002). The edema, epithelial lifting as well as lamellar fusion also are defence mechanisms that reduce the branchial superficial area in contact with the external milieu. These mechanisms also increase the diffusion barrier to the pollutant (Laurèn \& McDonald 1985, Van Heerden et al. 2004).

Lamellar axis vasodilatation was also found in tilapia exposed to copper. Garcia-Santos et al. (2006) refer that this lesion can induce changes in pillar cell normal structure, with consequent loss of their support function and probably, and was responsible for the emergence of lamellar aneurysms in fish exposed to cadmium. Similar results are observed by Thophon et al. (2003) in Lates calcarifer exposed to cadmium. However, Mallat (1985) suggests that these lesions are rarely associated to metals exposition.

The biological parameters are sometimes indicative of toxicant effects (Mayer et al. 1992). Our results reveal that the HSI increased with copper concentration. FigueiredoFernandes et al. (2006b) also found an increase of HSI in male and female tilapia, 0 . niloticus, exposed to paraquat. In contrast, rainbow trout Oncorhynchus mykiss injected with paraquat showed a decrease in the HSI after 9 weeks, however histological results were not shown (Åkerman et al. 2003).

The qualitative liver histology showed an increase on the hepatocytes size in tilapia exposed to copper that may be due to the high content of lipids. Huuskonen \& Lindström-Seppa (1995) and Stephensen et al. (2000) found that the high HSI observed in the perch (Perca fluviatilis) and sculpin (Myoxocephalus scorpius) can be indicative of increased activity of xenobiotic biotransformation enzymes. Figueiredo-Fernandes et al. (2006b) also suggested a positive relationship between the relative liver weight and the xenobiotic-metabolizing enzymes of tilapia exposed to paraquat.

The present work also shows that the number of hepatocytes nucleus in hepatic tissue decrease with the copper concentration. Several studies demonstrated that alterations in number, size and shape of the hepatocyte nucleus can be due to contaminants. Alterations in the size of nucleus have been previously regarded by Paris-Palacios et al. (2000) in Brachydanio rerio exposed to sublethal concentrations of copper sulphate. Braunbeck et al. (1990) referred that alterations in size and shape of nucleus have often been regarding as signs of increased metabolic activity but may be of pathological origin.

In a previous study the normal morphology of the liver of Nile tilapia, O. niloticus (Figueiredo-Fernandes et al. 2006c) was characterized, and it was shown that liver was made up of hepatocytes that were not oriented into distinct lobules but were arranged in branched laminae two cells thicks, separated by sinusoids. Hepatocytes were polygonal cells with a central spherical nucleus and a densely stained nucleolus. The present study also demonstrates that the liver of control fish exhibits a normal architecture and there were no pathological abnormalities. The hepatocytes present a homogenous cytoplasm and a large central or subcentral spherical nucleus.

The histology showed that copper caused some alterations of the liver parenchyma, like vacuolization and necrosis. The liver histological changes observed were more evident in fish exposed to high copper concentrations. These alterations are often associated with a degenerative-necrotic condition (Myers et al. 1987). Several studies had shown a variety of changes in the liver of 0 . niloticus, resulting from exposure to different toxic chemicals (Visoottiviseth et al. 1999, FigueiredoFernandes et al. 2006a,b). Moreover, it was also reported by several studies that chronic copper accumulation in the liver of fish causes hepatocyte lysis, cirrhosis and ultimately death (Pourahamad \& O'Brien 2000, Varanka et al. 2001).

In the present study gill and liver histological changes have been related to copper concentrations. It can be concluded that gill and hepatic alterations as a result of heavy metal exposition of fish may serve as a sensitive biomarker for the toxicity of sublethal concentrations of metals as well as other pollutants. However, complementary studies are necessary for a better understanding of its deleterious effects.

\section{REFERENCES}

Adham K.G., Hamed S.S., Ibrahim H.M. \& Saleh R.A. 2002. Impaired Functions in Nile Tilapia, Oreochromis niloticus (Linnaeus, 1757), from Polluted Waters. Acta Hydrochem. Hydrobiol. 29(5):278-288.

Åkerman G., Amcoff P., Tjärnlund U., Fogelberg K., Torrissen O. \& Balk L. 2003. Paraquat and menadione exposure of rainbow trout (Oncorhynchus mykiss): Studies of effects on the penthose-phosphate shunt and thiamine levels in liver and kidney. Chem. Biol. Int. 142:269-283.

Arellano J.M., Storch V. \& Sarasquete C. 1999. Histological changes and copper accumulation in liver and gills of the Senegales sole, Solea senegalensis. Ecotoxicol. Environ. Saf. 44:62-72.

Au D.W.T. 2004. The application of histo-cytopathological biomarkers in marine pollution monitoring: a review. Mar. Poll. Bull. 48:817-834.

Baker J.T.P. 1969. Histological and electron microscopical observations on copper poisoning in the winter flounder (Pseudopleuronectes americanus). J. Fish. Res. Bd. Can. 26:2785-2793.

Braunbeck T., Storch V. \& Bresch H. 1990. Species-specific reaction of liver ultrastructure in zebra fish (Brachydanio rerio) and trout (Salmo gairdneri) after prolonged exposure to 4-chloroaniline. Arch. Environ. Contam. Toxicol. 19:405-418.

Bury N.R., Li J., Flik G., Lock R.A.C. \& Wendelaar-Bonga S.E. 1998. Cortisol protects against copper induced necrosis and promotes apoptosis in fish gill chloride cells in vitro. Aquat. Toxicol. 40:193-202.

Campbell H.A., Handy R.D. \& Nimmo M. 1979. Copper uptake kinetics across the gills of rainbow trout (Oncorhyncus mykiss) measured using an improved isolated perfused head technique. Aquat. Toxicol. 46:177-190.

Chen J.C. \& Lin C.H. 2001. Toxicity of copper sulfate for survival, growth, molting and feeding of juveniles of the tiger shrimp, Penaeus monodon. Aquaculture 192:55-65.

De Boeck G., Vlaeminck A., Balm P.H., Lock R.A., De Wachter B. \& Blust R. 
2001. Morphological and metabolic changes in common carp, Cyprinus carpio, during short-term copper exposure: interactions between $\mathrm{Cu}^{2+}$ and plasma cortisol elevation. Environ. Toxicol. Chem. 20:374-381.

Farkas A., Salanki J. \& Specziar A. 2002. Relation between growth and the heavy metal concentration in organs of bream, Abramis brama L. populating lake Balaton. Arch. of Environ. Contam. Toxicol. 43(2):236-243.

Figueiredo-Fernandes A., Fontaínhas-Fernandes A., Monteiro R.A.F., ReisHenriques M.A. \& Rocha E. 2006a. Effects of the fungicide mancozeb in the liver structure of Nile tilapia, Oreochromis niloticus - Assessment and quantification of induced cytological changes using qualitative histopathology and the stereological point-sampled intercept method. Bull. Environ. Contam.Toxicol. 76(2):249-255.

Figueiredo-Fernandes A., Fontaínhas-Fernandes A., Peixoto F., Rocha E. \& ReisHenriques M.A. 2006b. Effect of paraquat on oxidative stress enzymes in tilapia Oreochromis niloticus at two levels of temperature. Pest. Biochem. Physiol. 85:97-103.

Figueiredo-Fernandes A., Fontaínhas-Fernandes A., Monteiro R., ReisHenriques M.A. \& Rocha E. 2006c. Temperature and gender influences on the hepatic stroma (and associated pancreatic acini) of Nile tilapia, Oreochromis niloticus (Teleostei, Cichlidae): A stereological analysis by light microscopy. J. Morphol. 267:221-230.

Fontaínhas-Fernandes A., Gomes E., Reis-Henriques M.A. \& Coimbra J. 1999. Replacement of fish meal by plant proteins in the diet of tilapia (Oreochromis niloticus): Digestibility and growth performance. Aquaculture Intern. 7:5767.

Gadagbui B.K.M., Addy M. \& Goksøyr A. 1996. Species characteristics of hepatic biotransformation enzymes in two tropical freshwater teleosts, tilapia (Oreochromis niloticus) and mudfish (Clarias anguillaris). Comp. Biochem. Physiol. 114C:201-211.

Garcia-Santos S., Fontaínhas-Fernandes A. \& Wilson J.M. 2006. Cadmium tolerance in the Nile tilapia (Oreochromis niloticus) following acute exposure: Assessment of some ionoregulatory parameters. Environ. Toxicol. 21(6):3346.

Gerbe 1996. "Toxicologie, Ecotoxicologie des pesticides et des métaux lourds", p.39. In: Premier rapport d'activité, Programme de Research Europol'Agro (ed.), Faculté de Sciences, Université de Reims Champagne-Ardenne, Reims, France.

Grosell M., Boetius I., Hansen H.J.M. \& Rosenkilde P. 1996. Influence of preexposure to sublethal levels of copper on $\mathrm{Cu}-64$ uptake and distribution among tissues of the European eel (Anguilla anguilla). Comp. Biochem. Physiol. C 114:229-235.

Huuskonen S. \& Lindström-Seppa P. 1995. Hepatic cytochrome P4501A and other biotransformation activities in perch (Perca fluviatilis): the effects of unbleached pulp mill effluents. Aquat. Toxicol 31:27-41.

Hwang P.P. \& Tsai Y.N. 1993. Effects of arsenic on osmoregulation in the tilapia Oreochromis mossambicus reared in seawater. Mar. Biol. 117:551-558.

Karan V., Vitorovic S., Tutundzic V. \& Poleksic V. 1998. Functional enzymes activity and gill histology of carp after copper sulfate exposure and recovery. Ecotoxicol. Environ. Safety 40:49-55.

Karlsson-Norggren L., Dickson W., Ljungberg O. \& Runn P. 1986. Acid water and aluminium exposure: gill lesions and aluminium accumulation in farmed, brown trout, Salmo trutta. L. J. Fish Dis. 9:1-9.

Kock G., Triendl M. \& Hofer R. 1996. Seasonal patterns of metal accumulation in Arctic char (Salvelinus alpinus) from an oligotrophic Alpine lake related to temperature. Can. J. Fish. Aquat. Sci. 53:780-786.

Laurèn D.J. \& McDonald D.G. 1985. Effects of copper on branchial ionoregulation in the rainbow trout, Salmo gairdneri Richardson: modulation by water hardness and pH. J. Comp. Physiol. B 155:635-644.

Laurent P. \& Perry S.F. 1991. Environmental effects on fish gill morphology. Physiol. Zool. 53:4-25.

Li J., Quabius S.E., Wendelaar Bonga S., Flick G. \& Lock R.A.C. 1998. Effects of water-borne copper on branchial chloride cells and $\mathrm{Na}^{+} / \mathrm{K}^{+}$-ATPase activities in Mozambique tilapia (Oreochromis mossambicus). Aquat. Toxicol. 43:1-11.
Mallatt J. 1985. Fish gill structural changes induced by toxicants and other irritants: a statistical review. Can. J. Fish. Aquat. Sci. 42:630-648.

Mayer F.L., Versteeg D.G., McKee M.J., Folmar L.C., Graney R.L., McCume D.C. \& Rattner B.A. 1992. Metabolic products as biomarkers, p.5-86. In: Hugget R.J., Kimerly R.A., Mehrle P.M. \& Bergman H.L. (ed.), Biomarkers: biochemical, physiological and histological markers of anthropogenic stress. Lewis Publishers, Chelsea, USA.

Mazon A.F., Cerqueira C.C.C. \& Fernandes M.N. 2002. Gill cellular changes induced by copper exposure in the South American tropical freshwater fish Prochilodus scrofa. Environ. Res. 88:52-63.

Monteiro S.M., Mancera J.M., Fontaínhas-Fernandes A. \& Sousa M. 2005. Copper induced alterations of biochemical parameters in the gill and plasma of Oreochromis niloticus. Comp. Biochem. Physiol. C. 141:375-383.

Myers M.S., Rhodes L.D. \& McCain B.B. 1987. Pathologic anatomy and patterns of occurrence of hepatic neoplasms, putative preneoplastic lesions, and other iodiopathic hepatic conditions in English sole (Parophrys vetulus) from Puget Sound, Washington. J. Natl Cancer. Inst. 78:333-363.

Nor Y.M. 1987. Ecotoxicology of copper to aquatic biota: A review. Environ. Res. 43:274-282.

Nowak B.F., Deavin J.G., Sarjito \& Munday B.L. 1992. Scanning electron microscopy in aquatic toxicology. J. Computer-Assisted Microsc. 4:241-246.

Olojo E.A.A., Olurin K.B., Mbaka G. \& Oluwemimo A.D. 2005. Histopathology of the gill and liver tissues of the African catfish Clarias gariepinus exposed to lead. Afr. J. Biotech. 4(1):117-122.

Pane E.F., Haque A. \& Wood C.M. 2004. Mechanistic analysis of acute, Niinduced respiratory toxicity in the rainbow trout (Oncorhynchus mykiss): an exclusively branchial phenomenon. Aquat. Toxicol. 69:11-24.

Paris-Palacios S., Biagianti-Risbourg S. \& Vernet G. 2000. Biochemical and (ultra)structural hepatic perturbation of Brachydanio rerio (Teleostei, Cyprinidae) exposed to two sublethal concentrations of copper sulphate. Aquat. Toxicol. 50:109-124.

Pelgrom S., Lamers L., Lock R., Balm P. \& Wendelaar Bonga S. 1995. Integrated physiological response of tilapia, Orechromis mossambicus, to sublethal copper exposure. Aquat. Toxicol. 32:303-320.

Perry S.F. \& Laurent P. 1993. Environmental effects on fish gill structure and function, p.231-264. In: Rankin J.C. \& Jensen F.B. (ed.), Fish Ecophysiology. Chapman and Hall, London.

Pourahamad J. \& O'Brien P. J. 2000. A comparison of hepatocyte cytotoxic mechanisms for $\mathrm{Cu}^{2+}$, and $\mathrm{Cd}^{2+}$. Toxicol. 143:263-273.

Randi A.S., Monserrat J.M., Rodriguez E.M. \& Romano L.A. 1996. Histopathological effects of cadmium on the gills of the freshwater fish, Macropsobrycon uruguayanae Eigenmann (Pisces, Atheinidae). J. Fish Dis. 19:311-322.

Reid S.D. \& McDonald D.G., 1988. Effects of cadmium, copper and low pH on ion fluxes in the rainbow trout, Salmo gairdneri. Can. J. Fish. Aquat. Sci. 45:244-253.

Rocha E. \& Monteiro R.A.F. 1999. Histology and cytology of fish liver: A review, p.321-344. In: Saksena D.N. (ed.) Ichthyology: Recent research advances. Science Publishers, Enfield, New Hampshire.

Rosety-Rodríguez M., Ordoñez F.., Rosety J.M., Rosety I., Ribelles A. \& Carrasco C. 2002. Morpho-histochemical changes in the gills of turbot, Scophthalmus maximus L., induced by sodium dodecyl sulfate. Ecotoxicol. Environ. Safety 51:223-228.

Schwaiger J., Ferling H., Mallow U., Wintermayr H. \& Negele R.D. 2004. Toxic effects of the non-steroidal anti-inflammatory drug diclofenac. Part $I$. Histopathological alterations and bioaccumulation in rainbow trout. Aquat. Toxicol. 68:141-150

Sola F., Isaia J. \& Masoni A. 1995. Effects of copper on gill structure and transport function in the rainbow trout, Oncorhynchus mykiss. J. Appl. Toxicol. 15:391-398.

Stephensen E., Svavarsson J., Sturve J., Ericson G., Adolfson-Erici M. \& Förlin L. 2000. Biochemical indicators of pollution exposure in shorthorn sculpin (Myoxocephalus scorpius), caught in four harbours on the south-west coast of Iceland. Aquat. Toxicol. 48:431-442. 
Teisseire H. 1999. Toxicologie et écotoxicologie des pesticides et des métaux lourds susceptibles d'être présents dans le vignoble champenois: étude de leur impact physiologique et biochimique sur Lemna minor. Université de Reims Champagne-Ardenne, Reims, France. 272 p.

Thophon S., Kruatrachue M., Upatham E.S., Pokethitiyook P., Sahaphong S. \& Jaritkhuan S. 2003. Histopathological alterations of white seabass, Lates calcarifer, in acute and subchronic cadmium exposure. Environ. Pollut. 121:307-320.

Van den Heuvel M.R., Power M., Richards J., MacKinnon M. \& Dixon D.G. 2000. Disease and gill lesions in yellow perch (Perca flavescens) exposed to oil sands mining-associated water. Ecotoxicol. Environ. Saf. 46:334341.

Van Heerden D., Vosloo A. \& Nikinmaa M. 2004. Effects of short-term copper exposure on gill structure, methallothionein and hypoxia-inducible factor- 1á (HIF-1á) levels in rainbow trout (Oncorhynchus mykiss). Aquat. Toxicol. 69:271-280.

Varanka Z., Rojik I., Varanka I., Nemcsók J. \& Ábrahám, M. 2001. Biochemical and morphological changes in carp (Cyprinus carpio L.) liver following exposure to copper sulfate and tannic acid. Comp. Biochem. Physiol. C 128:467-478.

Visoottiviseth P., Thamamaruitkun T., Sahaphong S., Riengrojpitak S. \& Kruatrachue M. 1999. Histopathological effects of triphenyltin hydroxide on liver, kidney and gill of Nile tilapia (Oreochromis nilotica). Appl. Organometal. Chem. 13:749-763.

WHO 1998. Copper. Environmental Health Criteria 200. IPCS-International Programme on Chemical Safety, World Health Organization, Geneva.

Wilson J. M. \& Laurent P. 2002. Fish gill morphology: inside out. J. Exp. Zool. 293:192-213. 